\title{
Analysis of search and rescue emergency evaluation in ship accidents in Indonesia
}

\author{
Arleiny ${ }^{1,1}$, Damoyanto Purba ${ }^{2}$, IIe Suwondo ${ }^{3}$, and Manungku Trinata $P^{4}$ \\ ${ }^{1}$ POLTEKPEL SBY, Nautica, Indonesia, \\ ${ }^{2}$ POLTEKPEL SBY, Nautica, Indonesia, , ${ }^{3}$ POLTEKPEL SBY, Nautica, Indonesia, ${ }^{4}$ POLTEKPEL \\ SBY, Nautica, Indonesia
}

\begin{abstract}
The objectives og this research is to describe the factors causing ship accident in Indonesia and know the effectiveness of SAR emergency in ship accident in Indonesia. The research method used in this research is qualitative research. Techniques Collection of literature study data and documents. Data validity method using triangulation. Data analysis uses interactive data analysis. The conclusions of this study are Factors that cause the occurrence of ship accidents in Indonesia, among others, the resources of the crew, the eligibility of ships, supporting facilities for shipping, operators, lack of supervision of apparatus, service users and other factors. The high number of ship accidents in Indonesia shows the ineffective implementation of SAR in ship accident in Indonesia.
\end{abstract}

\subsection{Introduction}

The shipping disruption can essentially be a disruption that can be directly addressed, even the need for direct assistance from a particular party, or disruption resulting in the skipper and all the crew having to be involved either to overcome the disruption or to leave the ship. The situation of the shipping disruption according to the situation can be grouped into an emergency based on the type of event itself which, among other things, collision, fire / explosion, rupture, leakage / drowning, people falling into the sea and pollution. Emergency conditions on ships may be detrimental to the Skipper and the crew and the owner of the ship and the link environment may even cause disruption of the 'seabed' ecosystem.

The sinking of the Tampomas II vessel is remembered as a very heartbreaking humanitarian tragedy. The incident on 27 January 1981 was the darkest history for the Indonesian maritime world. This calamity killed 369 people, both passengers and crew. Such negligence, a number of crew members received administrative sanctions by the Ship Court. The sluggish assistance to Motor Vessel (KM) Tampomas II also reflects poor coordination in rescue measures.

The causes of the accident on board are: (1) human error, (2) destruction of ship machinery, (3) external and internal factors, eg fire and impact events, (4) natural or weather factors, (5) a combination of all the causes. In general, the accident that may occur on the ship is the result: (1) collision with other vessels, (2) stranded / grounded, (3) drowning due to bad weather (bedweather), (4) burning ), (5) engine damage (engine black out / breakdown), and (6) ship juxtaposed with other vessels.

Research from Jori Nordstrom (2016) with the title Vessel TRIAGE: A method for assessing and communicating the safety status of vessels in maritime distress situation. The result of this research is An evaluation of the proposed method indicates a positive reception among various maritime stakeholders, suggesting that implementing the

1 Corresponding author: arleiny@poltekpel-sby.ac.id/arleinysudardi3@gmail.com 
Vessel TRIAGE method in maritime SAR procedures may act as a useful tool to assist in the management of maritime distress situations. As Wan Muhamad at all research (2014) human error and external factor to be the contributing factor is agreed the most by respondent is the factors that affecting the efficiency of the management of vessels.

Based on the above exposure the purpose of this study is to describe the factors that cause the occurrence of accidents on the ship in Indonesia and to determine the effectiveness of emergency SAR in ship accident in Indonesia

\subsection{Research Method}

The method of research conducted in the study this is using case study research methods and descriptive research methods. Study studies case is observing the behavior of that object intensively studied, while descriptive method (descriptive research), that is research method intended to describe phenomena that exists, which lasts as long as the author performs this research. Technique of collecting data in this research is bibliography and document. Data validity techniques use data triangulation and data analysis techniques using interactive analysis techniques

\subsection{Factors causing ship accidents in Indonesia}

Transportation services with a guarantee of safety will provide a sense of certainty and calm for the traveler or the owner of the goods, so that socio-economic activities of the community can be protected. If the safety aspect of transportation is guaranteed, and the rights of user communities are protected, there will be no unnecessary and counterproductive costs.

The principle of transportation safety has been the concern of the Government for a long time. In 1999, Presidential Decree No. 105/1999 on the establishment of the National Transportation Safety Committee (KNKT) was established. The safety principle, of course, became the government's reference through the Transportation Department when it launched the Road Map to Zero Accident program at the end of the first semester of 2007, in the sense that the government seeks to minimize accidents through accurately programmed activities with continuous control and control.

Based on the results of research that the authors obtained data as follows:

Table 1. Investigation Data of Navy KNKT Year Accident 2010- 2016

\begin{tabular}{|c|c|c|c|c|c|c|c|c|c|c|}
\hline \multirow[b]{2}{*}{ No. } & \multirow[b]{2}{*}{ TAHUN } & \multirow[b]{2}{*}{$\begin{array}{c}\text { JUMLAH } \\
\text { KECELAKAAN }\end{array}$} & \multicolumn{5}{|c|}{ JENIS KECELARAAN } & \multicolumn{2}{|c|}{ KORBAN JIWA } & \multirow[b]{2}{*}{ REKOMENDASI } \\
\hline & & & \begin{tabular}{|l|} 
TENGGELAM \\
\end{tabular} & \begin{tabular}{|l} 
TERBAKAAR/ \\
MELLDAK
\end{tabular} & TUBRUKAN & KANDAS & LAIN-LAIN & $\begin{array}{l}\text { KORBAN } \\
\text { MENNINGGAL } \\
\text { HIIANG }\end{array}$ & \begin{tabular}{|c|}
$\begin{array}{c}\text { KORBAN } \\
\text { UUKA-UKA }\end{array}$ \\
\end{tabular} & \\
\hline 1 & 2010 & 5 & 1 & 1 & 3 & 0 & 0 & 15 & 85 & 45 \\
\hline 2 & 2011 & 6 & 1 & 3 & 2 & 0 & 0 & 86 & 346 & 82 \\
\hline 3 & 2012 & 4 & 0 & 2 & 2 & 0 & 0 & 13 & 10 & 28 \\
\hline 4 & 2013 & 6 & 2 & 2 & 2 & 0 & 0 & 65 & 9 & 47 \\
\hline 5 & 2014 & 7 & 2 & 3 & 2 & 0 & 0 & 22 & 4 & 25 \\
\hline 6 & 2015 & 11 & 3 & 4 & 3 & 1 & 0 & 85 & 2 & 11 \\
\hline 7 & 2016 & 15 & 4 & 4 & 3 & 2 & 2 & 51 & 18 & 35 \\
\hline & TOTAL & 54 & 13 & 19 & 17 & 3 & 2 & 337 & 474 & 273 \\
\hline
\end{tabular}


Based on the above table, it can be seen that there is an increase in marine accidents from 2014, 2015 and 2016. Furthermore, it will be clarified on the graph as follows:

Graph I. Percentage of Type of Sea Transport Accident Year 2010 - 2016

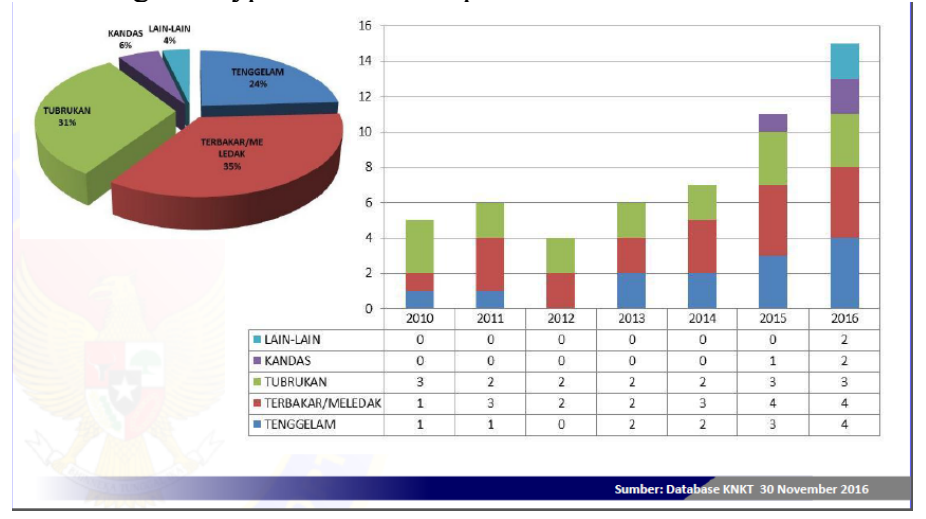

Based on the graph above, it can be seen that the Percentage of Type of Marine Transport Accident in 2010 - 2016 consists of railing, collision, collision / bursting and sinking. In the period 2010 - 2016 the highest accidents are burning / exploding and drowning.

From some data that has been writer collected can be known that the factors causing the occurrence of ship accident in Indonesia among others because (Danny Faturachman, 2012):

1. The resources of the crew

The crew must have the ability to navigate to cross its ships from one port to another, within certain limits of the voyage safely. They are also required to undertake an "economic voyage" that is to travel through the shortest distance safely from navigational hazards so that additional exploitation costs can be avoided.

2. Ship Ability

The ship is in excellent condition, and in accordance with the provisions of the legislation, and declared sea worthy, it would be safer to cross people and goods, on the contrary the ship is doubtful conditions tend to encounter obstacles while in the voyage. If the ship is damaged while on the go will require additional costs such as exploitation costs caused by the delay.

3. Sailing Supporting Facilities

In addition to the technical factors of ships and crew resources, the Sailing Navigation Supporting Facility (SBNP) is also a very important element in shipping safety. This facility consists of marine signs that serve as a guiding tool for sailing vessels, in order to avoid the dangers of navigation. The Coastal Radio Station is also useful as a means of navigating shipping to enable ships to make economical voyages, because without this instrument the vessel must make a "turn" voyage in order to avoid the danger of navigation 


\section{Operator}

Many ships are made traditionally / do not have certificates, shipbuilding does not follow the direction of ship image that has been legalized. Vessel certificate has expired, Communication equipment / navigation ship less functioning. Excessive loading is mainly on-deck. Incremental load / increment placement. Excessive passenger loading. Passenger awareness is still lacking.

5. Lack of supervision of the apparatus

The vessel can exit / enter the place where only The number of locations of supervisory apparatus is limited. Not all shipping places can be monitored. The possibility of examination is less thorough

6. Service User / Community

Lack of public awareness of the importance of shipping safety. Often impose the will regardless of the safety of the voyage. While the causal factors that directly cause the occurrence of marine accidents.

7. Other factors

Human factor is the biggest factor which among others include carelessness in running the ship (Anomin, 1998), lack of ability of the crew in mastering various problems that may arise in ship operations, Based on the above explanation, it can be analyzed that the factors that resulted in ship accidents in Indonesia, among others, due to loading of ships full of excess. Placement of vehicle cargo resulted in the ship having a trim bow (the ship is down). The rampa gate is not closed causing sea water to enter the vehicle deck. The certification process does not refer to the actual condition of the ship. The calculation of the stability of the ship can not be done due to limited time and no vehicle weight data.

\subsection{SAR emergency Effectiveness in ship accident in Indonesia}

The territory of the Republic of Indonesia consists of territorial waters and islands where as interconnection between islands in order to support the development of the economy is in terms of transportation. Conditions such as this impact transport traffic becomes very crowded. On the other hand public awareness about safety has not been a priority, so that in case of disaster.

A number of incidents of accidents occurring in Indonesian seas need to get attention because the intensity of the incident is still high. In 2014, about 450 incidents occurred in waters. Not only passenger ships, but also freight ships, and so forth. The accident also caused the spill of oil / diesel marine vessels, consequently the fish in the sea dead, sea water became polluted and garbage scattered to the bottom of the sea (Nina Nur Hasanah, 2015).

Based on the authors' analysis, there is an increasing number of ship accidents occurring from 2010 (5 accidents), 2011 (6 accidents), 2012 (4 accidents), 2013 (6 accidents), 2014 (7 accidents), 2015 (11 accidents) Year 2016 (15 crashes) (Secondary Data of KNKT, 2016).

Should be, every ship must have a system and procedures for prevention and prevention of the event of disturbance to the safety (safety) and in its implementation must appoint an officer responsible for supervising the safety of ships and the prevention of pollution from the ship.

In addition, the shipping company must appoint a Manager-level called DPA (Designated Person Ashore). He is responsible and oversees the safety of the Shipping Company. The responsible manager must be responsible and have direct access to the highest Management of the Shipping Company. Management of ships, does not conduct training on the prevention and prevention of safety interruption of shipping 
activities of the respective Shipping Company periodically to address and prevent safety, the Shipping Company must have facilities and equipment in accordance with the provisions of the ISM Code.

The ineffectiveness of SAR emergency in ship crash in Indonesia is due to several things, most of which captain has low compliance in checking boat with checklist so that the captains are easy to fill out inspection checklist by frequently checking inspection checklist without testing machine and test .

Based on the above explanation, it can be concluded that with the still high number of ship accidents in Indonesia due to lack of education and training for supervisors and crew of the ship this shows the ineffectiveness of the implementation of SAR on ship accident in Indonesia.

\subsection{The Acknowledgements}

First of all Thanks to GOD, for His mercy and guidance in giving me full strength to complete this paper. Special appreciation to my family for their support. Thanks.

\section{References}

Anonim. 1998. Improving the Continued Airworthiness of Civil Aircraft: A Strategy for the FAA's Aircraft Certification Service. The National Academies of Sciences, Engineering, and Medicine 500 Fifth St., NW | Washington, DC 20001

Danny Fathurahman, 2012. Analysis of Indoensian Ship Accident 2005 - 2010. Conference: International Conference on Computer, Electrical, and Systems Sciences, and Engineering (ICCESSE 2012), At Penang, Malaysia

Jori Nordström.Vessel TRIAGE: A method for assessing and communicating the safety status of vessels in maritime distress situations. Safety Science Volume 85, June 2016, Pages 117-129

Ketua Sub Komite Investigasi. Kecelakaan Pelayaran. Data Investigasi Kecelakaan Pelayaran Tahun 2010-2016. KNKT 2016

Nina Nurhasanah, Asmar Joni, Nur Shabrina. Persepsi Crew dan Manajemen dalam Penerapan ISM Code bagi Keselamatan Pelayaran dan Perlindungan Lingkungan Laut. PROSIDING SEMINAR NASIONAL MULTI DISIPLIN ILMU \& CALL FOR PAPERS UNISBANK (SENDI_U). Kajian Multi Disiplin Ilmu untuk Mewujudkan Poros Maritim dalam Pembangunan Ekonomi Berbasis Kesejahteraan Rakyat. ISBN: 978-979-3649-81-8

Wan Muhamad Amir W Ahmad1, Gobi Krishnan Veluplay2, Kasypi Mokhtar 3, Nurfadhlina Halim4 and Nor Azlida Aleng. Comprehensive analysis of the factors that affecting the efficiency of the management of Vessel Using LRM, RSM and SEM.. International Journal of Engineering and Applied Sciences. July. 2014. Vol. 5. No. 02 ISSN2305-8269 